\title{
The Effects of Commodities and Financial Markets on Crude Oil
}

\author{
Georgios Galyfianakis, Alexandros Garefalakis* and Georgios Mantalis \\ Accounting and Finance Department, Technological Education Institute of Crete, 71004 Iraklio - Greece \\ e-mail: galifianakis@sdo.teicrete.gr-garefalakis@teicrete.gr-mantalis10@hotmail.com \\ * Corresponding author
}

\begin{abstract}
Investigating crude oil price volatility is crucial, because crude oil price certainly affects the economy through many channels. This study applies a Vector Auto Regression (VAR) model to examine the impact of crude oil market on basic commodities, financial markets and industrial production. We find that the production in the US economy has an important effect on the crude oil prices. In addition we noticed a higher increase in crude oil price volatility after a large negative shock, contrary to a large positive one. Also, it was found that, in the short-run, oil price volatility is not influenced by short-run interest rates or industrial production. An adverse linkage between crude oil prices and industrial production has been proved confirming the economic theorists claiming that there is a close linkage between oil price shocks and economic activity. Finally, our findings indicate that there is Granger causality between crude oil and the endogenous variables used in the Granger causality framework.
\end{abstract}

Résumé - L'effet des matières premières et des marchés financiers sur le pétrole brut — L'étude de la volatilité du prix du pétrole brut est cruciale parce que le prix du pétrole brut influe certainement l'économie à travers de nombreux canaux. Cette étude applique un modèle VAR pour examiner l'impact du marché du pétrole brut sur des matières premières de base, sur les marchés financiers ainsi que sur la production industrielle. Nous trouvons que la production dans l'économie des USA a un effet essentiel sur les prix du pétrole brut. Par ailleurs, nous remarquons une augmentation plus haute de la volatilité du prix du pétrole brut après un grand choc pétrolier négatif, contrairement à un choc pétrolier considéré comme positif. En outre, il a été trouvé qu'à court terme, la volatilité du prix du pétrole n'est pas influencée par des taux d'intérêt à court terme ou par la production industrielle. Un lien défavorable entre les prix du pétrole brut et la production industrielle a été prouvé confirmant ainsi les théories des économistes revendiquant qu'il y a un lien étroit entre les chocs du prix du pétrole et l'activité économique. Finalement, nos conclusions indiquent qu'il y a une causalité de Granger entre le pétrole brut et les variables endogènes utilisées dans le cadre de causalité de Granger. 


\section{INTRODUCTION}

Since oil market is the most actively global traded commodity, which affects both the macroeconomics, such as inflation and Gross Domestic Product (GDP), and microeconomics, such as portfolio selection and pricing, aspects of economy, modeling and forecast crude oil price volatility is crucial for determining management risk (Sharma and Dharmaraja, 2016).

In order to explain oil prices behaviour three approaches have been mainly used (Fattouh, 2007). The most widespread approach is the non-renewable resources approach, as a basis for modeling the oil market concluding that oil prices should exhibit an upward trend (Kaufmann and Ullman, 2009). Based on these approach non-structural models for the behaviour of oil prices have been presented in the literature (Duffie and Gray, 1995). In contrast, in the supply-and-demand framework, the oil market is modeled by using behavioural equations linking the demand and supply equation by various determinants, such as GDP growth, oil prices, and the level of oil stocks (Dées et al., 2008; Garefalakis et al., 2011). Finally, the informal approach is sometimes used to interpret changes in oil prices on the basis of economic, geopolitical and secondary factors affecting the demand for and supply of oil.

For policy makers the volatility of oil prices is an important macroeconomic parameter while the way which oil prices evolve over time suggests that they face two separate but also related uncertainties (Guo and Kliensen, 2005). The first, refers to the trend of oil price, this because even if oil price follows and upward trend, policy maker should take into account the general impact of this increase to economy. Policy makers should realize the temporary nature of the certain changes in oil prices; however, the total economy is influenced by such fluctuations. In addition Kaufmann (2011) noticed oil price volatility can be affected by the behavior of market participants that engage - at least in short-run - speculation while Ewing et al. (2006) noticed that oil prices and their dynamics are broadly related to economic growth.

In order to modeling the oil price volatility, Salisu (2014), suggests that in markets with high-frequent time series Generalized AutoRegressive Conditional Heteroscedastic (GARCH) models and their modifications (EGARCH, etc.) work better than simple AutoRegressive Moving Average (ARMA) models, which they have homoscedastic nature (Sharma and Dharmaraja, 2016).

Engle (1982) trying to estimate the means and variances of inflation in UK developed a new AutoRegressive Conditional Heteroscedastic (ARCH) stochastic process. This process is basically a time series model which allows the conditional variance to change over the time as a function of the previous time periods' error terms, leaving the unconditional variance constant. More specifically, this model assumes Autoregressive Model (AM) for the error variance. Bollerslev (1986) extended the ARCH process in more general form by the assumption of ARMA model for the error variance. His method called GARCH in order to achieve more flexible lag structure. Table 1 presents the various modifications of GARCH models to oil market volatility.

This paper investigates the volatility of the crude oil market and dynamics with some other parameters. We specifically use monthly data for the period between April 2005 and December 2015 in order to examine the dynamics between, crude oil, US industrial production, and US 3-Month Interest Rates (US 3M. Int. Rates) and we model the volatility of oil price. We apply a Vector Auto Regression (VAR) (1) model, firstly because by using a VAR specification, a Granger causality test establishes that causality runs from (the change in) industrial production to the oil price and from (the change in) US 3M. Int. Rates to the oil price and, secondly, because the price of crude oil was found to Granger cause the metal index. Our findings suggest that US industrial production has important effect on the oil price and that volatility increases more after a large negative shock than after a large positive shock.

The purpose of our study is twofold, firstly to establish the causal relationships of some variables to the oil price and secondly to model the oil price volatility. The main contribution of this research to the literature of the oil price determinants is related to the examination of whether oil price volatility is influenced by factors that are found (through a VAR framework) to Granger-cause the change in oil prices; these factors are the US industrial production and the US 3M. Int. Rates.

The rest of the paper is organized as follows. Section 1 briefly summarizes the existing literature. Section 2 presents our methodology and data. Section 3 provides the empirical results of our study and finally, in the last section, paper provides some concluding remarks.

\section{LITERATURE REVIEW}

Volatility is not referring to a single parameter, but to a set of related concepts which only under restrictive assumptions could be summarized with a single number. Figlewski (1997) as well as Chatrath et al. (2015), emphasize to the central role of volatility in the economy. Pindyck (2004) argues that understanding the volatility of commodity prices is critical, because volatility could affect the total marginal cost of production and changes in volatility can expose producers and industrial consumers to risk.

Consequently, reliable oil price volatility forecasts modeling is crucial, so, they have been developed forecasting models that classified, in accordance that consideration 
TABLE 1

GARCH models modification and their applications to oil market volatility.

\begin{tabular}{|c|c|c|c|}
\hline Model & Feature & Model & Feature \\
\hline IGARCH & $\begin{array}{l}\text { Is better equipped to account for } \\
\text { this long memory in the volatility } \\
\text { due to the integration, of the } \\
\text { variance equation coefficients of } \\
\text { standard GARCH, over lag } \\
\text { variables. }\end{array}$ & GARCH_M & $\begin{array}{c}\text { Allows for the mean of the returns to } \\
\text { be a function of the conditional } \\
\text { volatility. }\end{array}$ \\
\hline GARCH (FIGARCH) & $\begin{array}{l}\text { It captures long memory shocks } \\
\text { effectively and provides a slow } \\
\text { decay of shocks over time. }\end{array}$ & Multivariate GARCH & $\begin{array}{l}\text { These models are useful when } \\
\text { simultaneously computing the } \\
\text { volatility of multiple assets. }\end{array}$ \\
\hline TGARCH \& GJR & $\begin{array}{l}\text { Adds another residual term to } \\
\text { the standard GARCH to account } \\
\text { for asymmetrical behavior in } \\
\text { volatility. }\end{array}$ & $\mathrm{CGARCH}$ & $\begin{array}{l}\text { It improves the modeling of long- } \\
\text { term effects by decomposing the } \\
\text { model into long-run and short-run } \\
\text { components. }\end{array}$ \\
\hline EGARCH & $\begin{array}{c}\text { Unlike the standard GARCH } \\
\text { models often restrict coefficients to } \\
\text { be positive, this model removes } \\
\text { this restriction. }\end{array}$ & NN-GARCH & $\begin{array}{l}\text { A hybrid model that incorporates } \\
\text { neural networks with GARCH } \\
\text { estimates the extreme values of } \\
\text { volatility more effectively than } \\
\text { GARCH models alone. }\end{array}$ \\
\hline HYGARCH & $\begin{array}{l}\text { Is a mixture of standard GARCH, } \\
\text { IGARCH and FIGARCH models. }\end{array}$ & & \\
\hline
\end{tabular}

Source: Matar et al. (2013), pp. 255.

of future volatility, into time series, which consider the historical evolution of prices and volatility models and the observation of derivatives prices (Chatrath et al., 2015). Poon and Granger (2003) in their study reviewed 93 different studies in order to examine if volatility is forecastable or not. They conclude that financial markets are clearly forecastable and highlighting that the matter is how ahead we could accurately forecast, while Bredin et al. (2011) argue that any fluctuations in industrial output can be explained by real options models.

Plourde and Watkins (1998) examined the price volatility between nine non-oil commodities (aluminum, copper, lead, nickel, tin, zinc, gold, silver, and wheat) and two crude oils (West Texas Intermediate (WTI) and Brent). They find that oil prices tend to be equal volatile, and some times more volatile, than those of most of the other commodities. Moreover they highlight that the differences between the price volatility of oil and the other commodities is most marked for precious then agricultural commodity. Kuper (2002) modeled the volatility by selecting - based on the information criterion SIC - a symmetrical GARCH $(1,3)$ model. Subsequently, they did not find a statistically significant estimate for the coefficient of the variable, using a Threshold AutoRegressive Conditional Heteroscedastic (TARCH) $(1,3)$ model, which captures the asymmetric impact on oil price volatility. In other words, the results of the study revealed that negative and positive shocks have the same effect on the volatility of oil price in the period under consideration. Also, they examined the volatility of monthly time series for the period 1970:01-2002:05. For that specific period and the frequency of our data, the preferred model was found to be the GARCH $(1,1)$ model.

Pindyck (2004) examines the behavior of natural-gas and crude-oil price volatility in the US since 1990 . He obtains a weekly series of volatility using the sample standard deviations of adjusted daily log price changes in spot and futures prices and in order to obtain estimates of conditional volatility he use GARCH models. He found a statistically significant positive time trend in volatility for natural gas and, oil and crude oil volatility. He finds out also some evidence which they suggest that crude oil volatility could be used to predictive natural gas volatility, but not the other way around. He notices that although volatility fluctuates considerably, shocks to volatility are short-lived.

Elder and Serletis (2010), use a model is based on a structural VAR, modified to accommodate GARCH-in-Mean errors to account the volatility of oil prices and to examine the direct effects on real economic activity. Their finding suggests that oil price volatility have negative and significant effect on real GDP, durables consumption, several components of fixed investment and industrial production. Bredin et al. (2011) used the same model to examine the effects of the option value to delay investment and production induced by volatility about oil prices in G-7 countries 
(Lemonakis et al., 2016a). They find negative and significant effect of oil price volatility on industrial production in four of the G-7 countries: Canada, France, the UK, and the US. Zhang and Wei (2010) examine the relation between crude oil and the gold market. They check the co-integration between these two commodities with a two-step procedure, provided by Engle and Granger (1987). Firstly they develop a VAR model to test the linear Granger causality and then they follow the Baek and Brock (1992) and Hiemstra and Jones (1994) approach to test the non linear Granger causality. Later they use the Permanent Transitory (PT) and the Information Share (IS) models to explore the price discovery issue. They find a long-term relationship between crude oil and gold markets, with the oil price volatility being more intensive than the price of gold.

Romano and Scandurra (2012) using a GARCH $(1,1)$ specification in each market, estimate the volatility of raw materials and identify two time periods which were characterized by different volatility, the former with low volatility and the latter in which volatility has increased. In the next step they split the sample in two sub-samples to estimate price responses for these two periods. In order to assess the asymmetries in price formation, they use an Asymmetric Error Correction Model (A-ECM). They notice that in the former, industrial gasoline price responses for a period of low volatility and a period with high volatility of oil prices. Accordingly in the latter, retail gasoline price responses for the same period of low and high volatilities of industrial prices. Summarize this, in the period marked by a large price volatility the degree of asymmetry tends to decrease.

Salisu and Fasanya (2012) compared the performance of oil price volatility models, in three periods: before, during, and after the outbreak of the global financial crisis, by using daily returns of crude oil WTI price. The results showed that the oil price was more volatile during the global financial crisis compared to the other two periods. Also, based on the appropriate selection criteria, the asymmetric GARCH models, namely the TGARCH $(1,1)$ and EGARCH $(1,1)$ models, were found to be better than the symmetrical $\operatorname{GARCH}(1,1)$ and GARCH_M $(1,1)$ models when it comes to modeling the volatility of oil prices. According to the authors, this finding indicates the existence of leverage effects in the oil market, which, if ignored when modeling oil prices, it is expected to lead to serious biases and to misleading conclusions.

Jo (2014) used a VAR model with time-varying stochastic volatility to investigate the effect of oil price uncertainty on global real economic activity. His results show that an oil price uncertainty shock has negative effects on world industrial production all else equal. Dave and Aye (2015) analyse the relationship between oil price volatility and savings in South Africa by the use of GARCH-in-mean VAR model to account for the volatility of oil prices.
They find a slight negative relationship between oil price volatility and savings.

More recent Bampinas and Panagiotidis (2015) applied a dynamic bootstrap causality analysis, to examine the relationship between oil and gold before and after the financial crisis (Lemonakis et al., 2016b). They found a stable relationship between oil and gold. In addition they noticed a linear and unidirectional causality running from oil to gold in pre-crisis period, while in post-crisis period they noticed a nonlinear and bidirectional causality relationship. Sariannidis et al. (2015) investigate a positive relation between crude oil and gold by applying a JGR-GARCH model and support that increasing integration and high volatility of energy commodity markets are both associated with financial crises and uncertainty in the global economy.

Robe and Wallen (2016) investigate the relation between the term structure of oil option-implied volatilities and world macroeconomic conditions. They use a regression assuming that oil implied volatility levels or term structures are related to macroeconomic fundamentals (world and US macroeconomics conditions), to physical-market conditions (OPEC surplus production capacity, Brent crude oil production, North-American crude oil production, Crude oil storage capacity and utilization) and to financial variables (financial stress, paper market liquidity, financial traders positions in crude oil paper markets, time-to-maturity effect). Their findings suggest that equity-market, which was quantified by using the implied volatility of Standard and Poor's S\&P 500 equity index (the VIX), is an effective control variable, while macroeconomic variables do not add much extra information regarding oil implied volatilities. In contrast they identify relation between oil implied volatilities and storage market tightness.

\section{METHODOLOGY AND DATA}

For modeling volatility we assume that the generating process for the percentage change in the oil price at time $t$, denoted as $R_{t}{ }^{1}$, has as follows

$$
R_{t}=E(R)+U_{t}
$$

where, $E\left(R_{S}\right)$ : the expected return; this return could be a function of certain variables, that is, $E(R)=k(\cdot) ; U_{t}$ : a disturbance term related with the percentage change of the oil price, at time period $t$. It is assumed that $U_{t} \sim N\left(0, \sigma_{U}^{2}\right)$.

In the above model $U_{t}$ represents a shock or an excess return of at time period $t$, since it represents the deviation of the return in oil price from the norm, i.e. the asset's expected value. Next, we define the information set

\footnotetext{
1 The oil price return is estimated as follows $R_{t}=\frac{\ln P_{t}}{\ln P_{t-1}}$.
} 
$I_{t-1}=\left\{U_{t-1}\right\}$, consisting only of the previous value $U_{t-1}$; that is, we do know the value of the disturbance term in the previous period.

Given this information set, the conditional variance of Equation (1) has as follows:

$$
\operatorname{var}\left(R_{t} \backslash I_{t-1}\right)=\operatorname{var}\left(U_{t} \backslash I_{t-1}\right)=h_{t}
$$

Now it remains to specify an expression for $h_{t}$. To begin with, in the GARCH $(1,1)$ model we have the following relationship describing the behavior of conditional variance,

$$
h_{t}=\alpha_{0}+\alpha_{1} U_{t-1}^{2}+\delta_{1} h_{t-1}+\left[z^{\prime} X\right]
$$

Equation (3) shows that the conditional variance of the oil price return at the time $t$ depends on the following four factors: a constant term; news regarding the oil price volatility of the previous period, i.e. $U_{t-1}^{2}-$ which is the ARCH term of model; the prediction about conditional volatility during the previous period (i.e. the GARCH term of the model); and lastly, some factors $X$ which are supposed to impact oil price volatility. In other words, the anticipated oil price volatility depends on its long-term volatility (the constant term), the anticipated oil price volatility in the last period (the GARCH term), and information regarding the observed oil price volatility in the previous period (the ARCH term).

We use monthly spot prices for crude oil West Texas Intermediate (WTI) traded on the US spot market at Cushing, Oklahoma center, gold, silver, industrial metals, US dollar to euro exchange rate, US industrial production, and US 3M. Int. Rates (Sariannidis et al., 2009). The sample totals 116 monthly observations and covers the period May, 2005 to December, 2014. Spot prices were chosen since trade in spot prices results in physical delivery and hence limit speculative aspects that are present in the corresponding future prices. The prices are extremely spiky due to the nature of energy markets with strong fluctuations (volatile markets); hence, we analyze the logarithms of prices.

Descriptive statistics aid our understanding of the nature and distributional characteristics for our data. They follow the stylized facts of financial econometrics. Jarque-Bera (JB) for normality is rejected. We were unable to reject the hypothesis that the level of each series was non stationary. Our analysis shows that the price series were non stationary in levels (i.e. we were unable to reject the hypothesis that the level of each series contained a unit root) (Tab. 2).

\section{EMPIRICAL RESULTS}

The empirical results of this study consist of two parts. The first part uses a VAR framework of causality from various factors to the oil price. In the second part the oil price volatility is modeled in a GARCH framework, including as exogenous variables the factors that there found to be Granger causing oil price change. As it will be seen, these factors are the change in US Industrial production and the change in the US $3 \mathrm{M}$. Int. Rates.

To estimate a VAR model, first a unit root test is employed in order to establish the degree of integration of each time-series variable. Then, only stationary time-series (i.e. normally the first difference of each time series) will be used toward the estimation of a VAR model. This estimation will be helpful in establishing the direction of causality among the endogenous variables of the VAR model. Finally, because time series (especially financial ones such as stock returns) exhibit changes in variance over time, and these changes tend to be serially correlated, with groups of highly volatile observations occurring together, we examine, whether the variance of the oil price is constant over time; this type of heteroskedasticity can be modeled of GARCH model.

Table 3 presents the results of the unit root tests (assuming the aforementioned econometric specification) for a number of time-series variables. Finally, the first differences of all four time-series variables are seen to be stationary.

The unit root results help us to determine the endogenous variables that will be used in the VAR model. These variables are; the crude oil price, the change in metal index, the change silver price, the change in gold price, the change in US industrial production, and the change in the US 3M. Int. Rates. The EUR/USD is used as an exogenous variable in order to examine whether there are lead-lag relationships among the endogenous variables. The data used are monthly and they run from 2005 to 2014 .

Table 4 presents the results from fitting various VAR model specifications. As it is seen from the table, in all such specifications, the appropriate lag length for the estimated VAR model with the indicated number of endogenous variables included is one. The selection of the lag length is based on a number of multivariate information criteria like the sequential modified Likelihood Ratio (LR) test statistic (each test at 5\% level), the Final Prediction Error (FPE), the Akaike Information Criterion (AIC), and the Schwarz Information Criterion (SC).

\subsection{Granger Causality Test}

Granger causality test provides a definition of causality between a set of variables in the short-run. It denotes that a variable $X$ causes another variable $Y$ if present $Y$ can be better predicted by using past values of $X$. Feedback occurs if $X$ causes $Y$ and $Y$ causes $X$.

Using the lag-specification suggested by the laglength criteria of the VAR models depicted in Table 4, 
TABLE 2

Descriptive statistics.

\begin{tabular}{c|c|c|c|c|c|c|c}
\hline & Oil & EUR/USD & Metal & Gold & Ind. production & US 3M. Int. Rate & Silver \\
\hline Std. dev. & 19.50180 & 0.087773 & 41.69958 & 390.5010 & 5.849604 & 1.889946 & 856.1798 \\
\hline Skewness & -0.061530 & 0.619408 & -0.514731 & 0.009462 & -0.507353 & 1.012452 & 0.726461 \\
\hline Kurtosis & 2.761776 & 3.357756 & 2.907574 & 1.828851 & 2.687991 & 2.246650 & 2.580858 \\
\hline Jarque-Bera & 0.341498 & 7.897614 & 5.074596 & 6.516754 & 5.353146 & 22.17190 & 10.86164 \\
\hline Probability & 0.843033 & 0.019278 & 0.079080 & 0.038451 & 0.068799 & 0.000015 & 0.004380 \\
\hline Sum & 9418.260 & 153.0031 & 24629.70 & 126229.4 & 12097.30 & 153.1300 & 225611.6 \\
\hline Sum sq. dev. & 42976.17 & 0.870558 & 196490.6 & 17231483 & 3866.618 & 403.6241 & 82833951 \\
\hline Observations & 116 & 116 & 116 & 116 & 116 & 116 & 116 \\
\hline
\end{tabular}

The sample period covers the years 2005-2015 and contains 116 monthly observations.

TABLE 3

Unit root test.

\begin{tabular}{c|c|c}
\hline & Level & First difference \\
\hline Crude oil & -3.40 & $-8.44^{*}$ \\
\hline Euro/US dollar & -1.78 & $-11.66^{*}$ \\
\hline Gold & -0.87 & $-13.14^{*}$ \\
\hline $\begin{array}{c}\text { Industrial production } \\
\text { index (USA) }\end{array}$ & -2.44 & - \\
\hline $\begin{array}{c}\text { 3-Month Treasury } \\
\text { bill }\end{array}$ & -1.09 & $-6.92^{*}$ \\
\hline Metal spot index & -2.48 & $-10.55^{*}$ \\
\hline
\end{tabular}

* Indicates statistically significant estimate at $5 \%$.

a Granger causality test are run in order to determine whether there is any causality running from the endogenous variables to oil (Granger, 1999). Note all endogenous variables used in the Granger causality framework must be stationary, a fact that was proven in Table 3. The last row of Table 4 shows the results of the Granger causality test, that is, it shows the direction of causality running from one variable to another. These results are based on the significance value of the reported chi-square statistic with one degree of freedom (corresponding to the one optimal lag length of the VAR). The results of this test present evidence of causality, at the $5 \%$ level, running from (the change in) industrial production to the oil price and from (the change in) of US 3M. Int. Rates to the oil price in all model specification. Further, in three model specifications the oil price was found to Granger cause the price of the metal index while in two model specifications the oil price was found to Granger cause the price of gold.
The results of the causality test will be used in order to define the impulses and the responses in the estimated VAR (1) model. Since, as it was seen in Table 4 that, in all model specifications, causality runs from the change in US industrial production to the price of oil, we define the former variable as the impulse and the latter two as the response. The effect of a one-standard deviation shock in the change of the US industrial production and the change in the US 3M. Int. Rates is examined. The two impulse response functions, shown in the following Figure 1, trace out the responsiveness of WTI oil price in a one-standard-deviation shock in the change of the US industrial production and the US 3M. Int. Rates. If we consider the effect of oil prices to interest rates, then theoretically, there must be an inverse relationship between interest rates and the oil price for two reasons. First, when rates increase, consumption spending, including spending on automobiles and gas drops, since gas and automobiles are complementary goods. And since gas is derived from crude oil the fall in the demand for gas translates to weaker demand for oil, which ultimately causes oil prices to drop. Second, higher interest rates mean a stronger dollar, so it may be possible for oil produces (who get paid in dollar) to pass on the savings brought about by a stronger dollar on to consumers.

Figure 1 clearly shows the effect of a (positive) shock in the latter two variables on the oil price is positive. Specifically, the effect of a positive shock in the US 3M. Int. Rates is higher than the effect of the US industrial production and, the effect reaches a maximum 3 months after the shock.

Figure 2 presents monthly percentage change in the crude Oil-WTI spot price index for the period under our investigation. It is evident from this graph that the percent price changes in the crude oil price exhibit considerable volatility. Notice especially the wide swing around mid 2008 where oil prices peaked $\$ 145$ per barrel. 
TABLE 4

VAR model estimation and model selection.

\begin{tabular}{|c|c|c|c|}
\hline Endogenous variables & Model 1 & Model 2 & Model 3 \\
\hline Oil & Yes & Yes & Yes \\
\hline$\Delta($ Metal index $)$ & & Yes & Yes \\
\hline$\Delta$ (Gold) & & & Yes \\
\hline \multicolumn{4}{|l|}{$\Delta$ (Silver) } \\
\hline$\Delta$ (US industrial production) & Yes & Yes & Yes \\
\hline$\Delta(3 \mathrm{M}$. Int. Rate) & Yes & Yes & Yes \\
\hline Exogenous variable EUR/USD & Yes & Yes & Yes \\
\hline Optimal lag length & 1 & 1 & 1 \\
\hline Causality result & $\begin{array}{c}\text { Ind. production } \rightarrow \mathrm{Oil}^{* *}, \\
\text { Int. rate } \rightarrow \mathrm{Oil}^{*}\end{array}$ & $\begin{array}{c}\text { Ind. production } \rightarrow \text { Oil, } \\
\text { Int. rate } \rightarrow \text { Oil } \\
\text { Oil } \rightarrow \text { Metals }\end{array}$ & $\begin{array}{c}\text { Ind. production } \rightarrow \text { Oil, } \\
\text { Int. rate } \rightarrow \text { Oil, } \\
\text { Oil } \rightarrow \text { Metals, } \\
\text { Oil } \rightarrow \text { Gold }\end{array}$ \\
\hline
\end{tabular}

${ }^{*, * *}$ Indicate statistically significant chi-square value at $5 \%$ and $10 \%$, respectively level of significance.

Sample: 2005M05 2014M12. The optimal lag-length has been chosen based on the following information criteria LR: sequential modified LR test statistic, FPE: Final Prediction Error, AIC: Akaike Information Criterion, and SC: Schwarz Information Criterion.

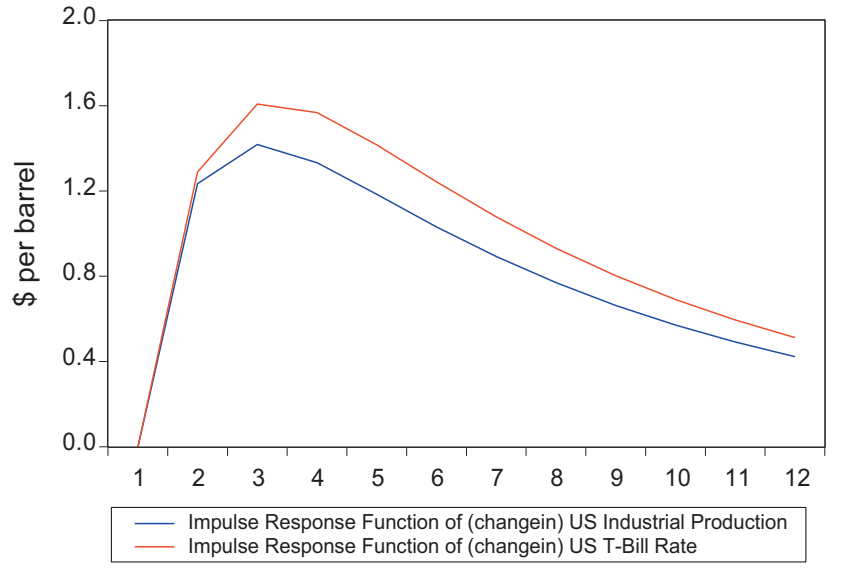

Figure 1

Response of oil price to US industrial production and the T-bill rate.

The simplest model for volatility estimate is the historical estimate, i.e. the variance (or standard deviation) of the percentage change in oil price over the historical period 2005:05-2014:12. Table 5 shows the percentage change in oil price, along with an estimate of 0.1022 for the oil price volatility (this is simply the standard deviation of the percentage oil price changes).

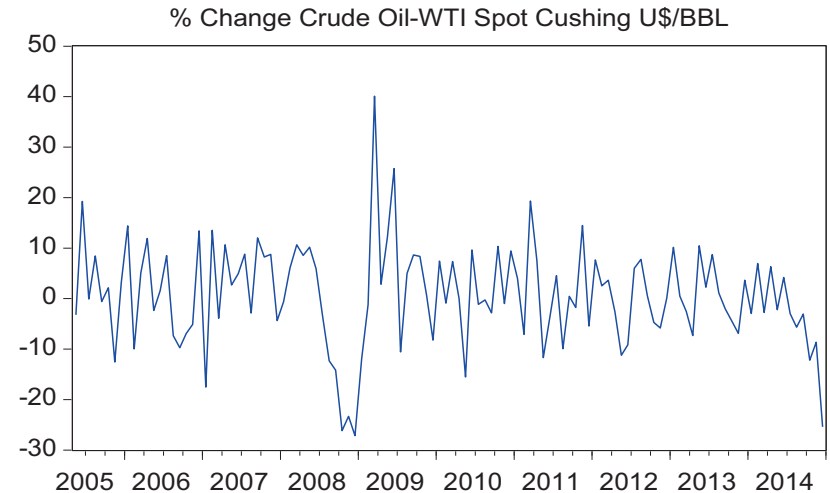

Figure 2

Percentage change in the oil price. Source: Bloomberg.

The estimation result of Standard Deviation (0.1022) becomes the volatility forecast of oil price for all future periods. However the assumption of constant future oil price volatility may not be a valid assumption. To this end, this section, with the use of a GARCH model, tests whether future oil price volatility can be considered to be constant or varying.

To capture the oil price volatility seen in the above table, the GARCH $(1,1)$ model is estimated, as it is shown by 
TABLE 5

Percentage change in oil price (volatility).

\begin{tabular}{c|c}
\hline Mean & 0.000938 \\
\hline Median & 0.002683 \\
\hline Std. dev. & 0.102222 \\
\hline Skewness & -0.447458 \\
\hline Kurtosis & 4.576756 \\
\hline Jarque-Bera & 15.88749 \\
\hline Probability & 0.000355 \\
\hline Observations & 116 \\
\hline
\end{tabular}

Equation (3). The mean equation, defined as in Equation (1), includes as a dependent variable the percentage change of the oil price, or log "return" of the oil at time $t$; this equation models the data generating process for the percentage change in the oil price. Then the variance Equation (3) describes the one-period ahead forecast variance based on past information; this conditional variance equation is a function of three terms: (a) the mean long-term volatility $\alpha_{0}$; (b) news about volatility from the previous periods, measured as the lag of the squared disturbance term $\left(\varepsilon_{t}^{2}\right)$ from the mean (the order of the ARCH term); and (c) previous period forecast variance (the order of the GARCH term).

Table 6 reports the results from estimating two model specifications for the GARCH $(1,1)$ model concerning the percentage change in the oil price. There are several important things to notice from the results of this table. First, in all model specifications the estimated coefficients $\hat{a}_{1}$ and $\hat{\delta}_{1}$ are statistically significant, a fact indicating the presence of $\mathrm{ARCH}$ and GARCH effects, respectively, on the percentage change of the oil price over the sample estimation period. In other words, the previous month's in the percentage change of the oil price $\left(\varepsilon_{t-1}^{2}\right)$ increase the current month volatility in the oil price. Second, the estimated constant $\hat{a}_{0}$ signifies that the average percentage change in the oil price is close to $1 \%$. But since the estimate for the constant is not statistically significant, we can assume that the average percentage change in the oil price, over the period of investigation is essentially zero. Third, the sum of the estimates $\hat{a}_{1}$ and $\hat{\delta}_{1}$ are substantially lower than unity.

This implies that the unconditional variance of the percentage change in oil prices can be defined, and shocks to the conditional variance of the percentage change of oil price will not be persistent.

Finally, by the model specifications we see that the change in industrial production and the change in US 3M. Int. Rates (both of which enter the variance equation) do
TABLE 6

Results from the estimation of the GARCH $(1,1)$ model.

\begin{tabular}{c|c|c|c}
\hline Variable & Model 1 & Model 2 & Model 3 \\
\hline $\begin{array}{c}\text { Estimated } \\
\text { coefficient }\end{array}$ & \multicolumn{3}{|c}{ Mean equation } \\
\hline$\mu$ & 0.011799 & 0.01036 & 0.0097 \\
\hline $\begin{array}{c}\text { Estimated } \\
\text { coefficient }\end{array}$ & & 0.002064 & 0.002093 \\
\hline$\alpha_{0}$ & $0.001907^{* *}$ & $0.2440^{* *}$ & $0.2705^{* *}$ \\
\hline$\alpha_{1}$ & $0.304584^{*}$ & $0.5621^{*}$ & $0.5402^{*}$ \\
\hline$\delta_{1}$ & $0.524868^{*}$ & -0.0005 & -0.0005 \\
\hline $\begin{array}{c}\Delta(\text { Industrial } \\
\text { production })\end{array}$ & & & 0.0005 \\
\hline $\begin{array}{c}\Delta(3 \mathrm{M} \text { T-Int. } \\
\text { Rate) }\end{array}$ & & & \\
\hline
\end{tabular}

${ }^{*}$ Statistically significant estimate at the $5 \%$ level of significance.

${ }^{* *}$ Statistically significant estimate at the $10 \%$ level of significance. Sample (adjusted): May 2005-December 2014.

not affect the oil price volatility in the short-run. Thus, although the price of oil depends on the change of the US industrial production and the 3-Month T-bill rate, the oil price volatility depends on its own shocks, such as $\mathrm{ARCH}$ and GARCH, but it is not influenced, in the short-run by volatility in US industrial production or the American short-term interest rates.

\section{CONCLUSION}

Crude oil prices exhibit noticeable price volatility during the last decade. Changes in oil prices tend to be permanent, difficult to predict and governed by different regimes and different determinant factors apart from the fundamentals of supply and demand that we used to know during the $80 \mathrm{~s}$ and $90 \mathrm{~s}$. Consequently, one view is that oil price behavior is due to the fundamentals of the economic theory but unquestionably according to the theory, financial markets, commodity markets and speculation play a very active role causing deviations from the equilibrium price and attracts many scientific arguments and works. In this paper we study mainly the interaction between the crude oil market, the US industrial production and short-term interest rates using a VAR framework over the period 2005-2014. We investigated as well the relation of crude oil with other commodities (gold and silver).

Summarizing the basic conclusions that can be derived from the empirical evidence of this paper we could say that the production in the US economy, with the country being 
the main consumer for oil world-wide, has an important effect on the oil price. Shocks to the oil price were not found to exhibit signs of persistence. It was found that oil price volatility increases more after a large negative shock than after a large positive shock indicating asymmetric effects on positive and negative price changes. Also, it was found that, in the short-run, oil price volatility is not influenced by short-run interest rates or industrial production. An adverse linkage between oil prices and industrial production has been proved confirming the economic theorists claiming that there is a close linkage between oil price shocks and economic activity.

Lastly, our findings indicate that there is Granger causality between oil and the parameters under investigation and therefore a strong correlation between the current and the past values. Our results of this test present evidence of causality running from industrial production to the oil price and from US 3M Int. Rates to the oil price in all model specification. Further, in three model specifications the oil price was found to Granger cause the price of the gold index confirming the literature of positive relation between crude oil and gold prices. This can be explained as a result of inflationary pressures that associated with oil spikes and hence, increase demand and the price of precious metals.

In our paper a number of theories were reviewed testing in the short-run - the selected data and confirming the relevant literature with our empirical results. Our results could lead us to a further research using other econometric models of empirical analysis and contributing more substantially to the relevant discussion. More specifically, we could examine the dynamic relation between basic traded commodities using high frequency data and recent long memory econometric methods.

\section{REFERENCES}

Baek E., Brock W. (1992) A general test for nonlinear Granger causality: bivariate model, Working paper, Iowa State University and University of Wisconsin, Madison.

Bampinas G., Panagiotidis T. (2015) On the relationship between oil and gold before and after financial crisis: linear, nonlinear and time-varying causality testing, Working paper, WP 15-04, The Rimini Centre for Economic Analysis, Italy.

Bollerslev T. (1986) Generalized autoregressive conditional heteroskedasticity, J. Econom. 31, 307-327.

Bredin D., Elder J., Fountas S. (2011) Oil volatility and the option value of waiting: an analysis of the G-7, J. Fut. Mark. 31, 679-702.

Chatrath A., Miao H., Ramchander S., Wang T. (2015) The forecasting efficacy of risk-neutral moments for crude oil volatility, J. Forecast. 34, 177-190.

Dave D., Aye G.C. (2015) Oil price uncertainty and Savings in South Africa, OPEC Energy Review 39, 285-297.
Dées S., Gasteuil A., Kaufmann R., Mann M. (2008) Assessing the factors behind oil price changes, Working paper No. 855, European Central Bank.

Duffie D., Gray S. (1995) Volatility in energy prices, in Managing energy price risk, Jamson R. (ed.), Risk Publications, London, pp. 39-55.

Elder J., Serletis A. (2010) Oil price uncertainty, J. Money, Credit Bank. 42, 1138-1159.

Engle R.F., Granger C.W.J. (1987) Co-integration and errorcorrection: representation, estimation and testing, Econometrica 55, 251-276.

Engle R.F. (1982) Autoregressive conditional heteroskedasticity with estimates of the variance of United Kingdom inflation, Econometrica 50, 987-1007.

Ewing B.T., Hammoudeh S.M., Thompson M.A. (2006) Examining asymmetric behavior in US petroleum futures and spot prices, Energy J. 27, 9-23.

Fattouh B. (2007) Structural model, the demand-supply framework and informal approaches, University of London, London, UK.

Figlewski S. (1997) Forecasting volatility, Financ. Mark. Inst. Instrum. 6, 2, 1-88.

Garefalakis A., Dimitras A., Koemtzopoulos D., Spinthiropoulos K. (2011) Determinant factors of Hong Kong stock market, Inter. J. of Fin. Mar. and Der. 62, 50-64.

Granger C. (1999) Empirical modeling in economics, Cambridge University Press, UK.

Guo H., Kliensen K. (2005) Oil price volatility and US macroeconomic activity, Fed. Res. Bank of St. Louis Rev. 87, 6, 669-683.

Hiemstra C., Jones J. (1994) Testing for linear and nonlinear Granger causality in the stock price-volume relation, J. Finance 49, 1639-1664.

Jo S. (2014) The effects of oil price uncertainty on global real economic activity, J. Money, Credit Bank. 46, 1113-1135.

Kaufmann R. (2011) The role of market fundamentals and speculation in recent price changes for crude oil, Energy Policy 39, 105-115.

Kaufmann R., Ullman B. (2009) Oil prices, speculation and fundamentals: interpreting causal relationship among spot and futures prices, Energy Econ. 31, 550-558.

Kuper G. (2002) Measuring oil price volatility, Department of Economics \& SOM, University of Groningen, The Netherlands.

Lemonakis C., Vassakis K., Garefalakis A., Papa P. (2016a) SMEs performance and subsidies in it investments: a vis-à-vis approach, J. of Theor. and App. Infor. Tech. 87, 2, 266-275.

Lemonakis C., Vassakis K., Garefalakis A., Michailidou D. (2016b) Cooperations characteristics for potential innovative in crisis: the Greek paradigm, Corp. Owner. and Control 14, 1, 30-37.

Matar W., Al-Fattah S.M., Atalla T., Pierru A. (2013) An introduction to oil market volatility analysis, OPEC Energy Rev. 37, 3, 247-269.

Pindyck R.S. (2004) Volatility and commodity price dynamics, J. Fut. Mark. 24, 1029-1047.

Plourde A., Watkins G.C. (1998) Crude oil prices between 1985 and 1994: how volatile in relation to other commodities? Resour. Energy Econ. 20, 245-262.

Poon S.-H., Granger C.W.J. (2003) Forecasting volatility in financial markets: a review, J. Econ. Lit. 41, 2, 478-539. 
Robe M.A., Wallen J. (2016) Fundamentals, derivatives market information and oil price volatility, J. Futures Mark. 36, 317-344. Romano A.A., Scandurra G. (2012) Price asymmetries and volatility in the Italian gasoline market, OPEC Energy Rev. 36, 215-229.

Salisu A.A. (2014) Modeling oil price volatility before, during and after the global financial crisis, OPEC Energy Rev. 38, 469-495.

Salisu A., Fasanya I. (2012) Modelling oil price volatility with structural breaks, Energy Policy 52, 554-562.

Sariannidis N., Galyfianakis G., Drimpetas E. (2015) The effect of financial and macroeconomic factors on the oil market, Inter. J. of Ener. Econ. and Pol. 5, 4, 1084-1091.

Sariannidis N., Koskosas I., Garefalakis A., Antoniadis I. (2009) Volatility of stock returns: the case of the Belgian Stock Exchange, Inter. J. of Bus. For. and Mark. Intel. 1, 111-121.
Sharma H., Dharmaraja S. (2016) Effect of outliers on volatility forecasting and value at risk estimation in crude oil markets, $O P E C$ Energy Rev. 40, 276-299.

Zhang Y.-J., Wei Y.-M. (2010) The crude oil market and the gold market: evidence for co-integration, causality and price discovery, Resour. Policy 35, 3, 168-177.

Manuscript submitted in October 2016 Manuscript accepted in December 2016 Published online in February 2017

Cite this article as: G. Galyfianakis, A. Garefalakis and G. Mantalis (2017). The Effects of Commodities and Financial Markets on Crude Oil, Oil Gas Sci. Technol 72, 3. 